\author{
Дідух C.M. \\ кандидат економічних наук \\ кафедра економіки промисловості \\ Одеська національна академія харчових технологій \\ вул. Канатна, 112, м. Одеса, Україна, 65039 \\ E-mail: didukhsm@i.ua
}

\title{
ВИКОРИСТАННЯ КЛАСТЕРНОЇ МОДЕЛІ ДЛЯ РЕАЛІЗАЦІЇ ІНВЕСТИЦІЙНОГО ПОТЕНЦІАЛУ ПЛОДООВОЧЕВИХ КОНСЕРВНИХ ПІДПРИЕМСТВ
}

У статті розглянуто передумови використання кластерної моделі розвитку для реалізації інвестиційного потенціалу плодоовочевих консервних підприємств України. Розглянуто стан та проблеми функціонування підприємств консервної галузі. Запропоновано схему організації та взаємодії учасників плодоовочевого кластеру. Визначено структуру плодоовочевого кластера, мету та завдання його створення, повноваження, обов'язки учасників і керівних органів. Представлено можливі ефекти від впровадження організаційних заходів з підвищення інвестиційного потенціалу плодоовочевих консервних підприємств.

Ключові слова: кластерна модель розвитку, інвестиційний потенціал, плодоовочеві консервні підприємства, плодоовочевий кластер.

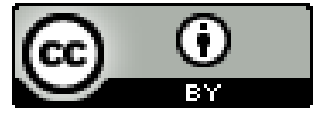

This work is licensed under a Creative Commons Attribution 4.0 International License http://creativecommons.org/licenses/by/4.0/
Постановка проблеми та ії зв'язок із важливими науковими та практичними завданнями. Враховуючи несприятливі зміни зовнішнього середовища, виробники продуктів харчування не можуть реалізувати накопичений інвестиційний потенціал. Однією iз причин цього є відсутність ефективних організаційноекономічних механізмів взаємодії сільськогосподарських виробників, переробних підприємств, торгівельних компаній, органів влади та наукових організацій. Підприємствам 3 виробництва продуктів харчування необхідні нові організаційно-економічні підходи, які дадуть змогу змінити негативний тренд падіння обсягів виробництва та вийти на траєкторію прискореного розвитку галузі та їі виробництв.

Актуальним та перспективним напрямом трансформації економічної системи $є$ впровадження кластерної моделі розвитку. Світовий досвід дає приклади результативного створення і функціонування кластерів у різних сегментах економіки. Їх спільною рисою $€$ підвищення продуктивності у самому кластері, та в суміжних секторах економіки внаслідок отримання синергетичного ефекту. Аналіз свідчить, що кластеризація $\epsilon$ однією 3 перспективних моделей розвитку та здатна забезпечити необхідну динаміку економічного зростання. Тому актуальною науковою задачею $є$ дослідження та обгрунтування можливості впровадження кластерної моделі розвитку для реалізації інвестиційного потенціалу підприємств з виробництва продуктів харчування та напоїв, зокрема плодоовочевих консервних підприємств.

Аналіз останніх публікацій по проблемі. Питання впровадження кластерної моделі розвитку розглядаються такими вітчизняними та закордонними вченими, як І.А. Брижань [1], М.П. Войнаренко [2], І.Ю. Спіфанова [3], Ю.Б. Іванов [4], Г. В. Іванченко [5], І.П. Продіус [6], П.Т. Саблук [7], В Asheim [8], М. E. Porter [9], S. A. Rosenfeld [10], M. J. Waits [11]. Водночас недостатньо дослідженими залишаються питання взаємодії учасників кластеру та визначення ефектів від його впровадження, що обумовило мету даної статті.

Формулювання цілей дослідження. Метою дослідження є обгрунтування організаційного напряму реалізації інвестиційного потенціалу плодоовочевих консервних підприємств, який полягає у впровадженні кластерної моделі розвитку.

Виклад основних результатів та їх обгрунтування. Поточна ситуація у харчовій промисловості характеризується спадом виробництва практично усіх основних видів продуктів харчування, окрім олії, м'яса, молока та вершкового масла. Не оминула ця тенденція і виробників плодоовочевої консервної продукції (табл. 1). 
Таблиця 1

Динаміка виробництва окремих видів плодоовочевої консервної продукції у 2011-2014 рр. [12]

\begin{tabular}{|l|c|c|c|c|c|}
\hline & 2011 p. & 2012 p. & 2013 p. & 2014 p. & $\begin{array}{c}\text { Відхилення } \\
2014 \text { р. до 2011 p. }\end{array}$ \\
\hline Соки фруктові та овочеві, тис.т & 382 & 452 & 463 & 440 & 58 \\
\hline Суміші соків фруктових та овочевих, тис.т & 330 & 309 & 286 & 246 & -84 \\
\hline Овочі консервовані натуральні, тис.т & 154 & 125 & 118 & 144 & -10 \\
\hline $\begin{array}{l}\text { Джеми, желе фруктові, пюре та пасти фру- } \\
\text { ктові чи горіхові, тис.т }\end{array}$ & 59,4 & 65,1 & 66,5 & 59,1 & $-0,3$ \\
\hline \multicolumn{1}{|c|}{ Усього } & 925,4 & 951,1 & 933,5 & 889,1 & $-36,3$ \\
\hline
\end{tabular}

Виробництво соків за підсумками 2014 р. знизилось на 3,7 \% по відношенню до 2011 р., овочів консервованих натуральних - на 6,5\%. Зменшення обсягів виробництва триває 32007 р., коли в Україні було вироблено 1077 тис. т. плодоовочевих консервів.

Цей спад має низку об'єктивних причин: зменшення рівня споживання продукції через падіння доходів населення, часткова втрата експортних ринків, зменшення чисельності населення, високий рівень зношеності виробничих фондів, недостатня економічна ефективність виробництва тощо.

Враховуючи важливу роль плодоовочевих консервних підприємств у забезпеченні повноцінного харчування та продовольчої безпеки населення, актуальною задачею $є$ пошук ефективних шляхів виходу галузі із кризового стану.

Для цього необхідно об'єднати зусилля усіх учасників ринку за такими напрямками: покращення сировинного забезпечення переробних підприємств; розвиток логістики, заготівельної та збутової інфраструктури; покращення інформаційного та маркетингового забезпечення; покращення якості та асортименту продукції; оптимізація собівартості продукції; збільшення рентабельності виробництва; підвищення інвестиційної привабливості галузі.
Галузь із виробництва плодоовочевих консервів має значний потенціал для розвитку за рахунок сприятливих кліматичних та географічних умов.

В умовах дефіциту інвестиційних ресурсів 3 метою реалізації наявних інвестиційних можливостей необхідно більш активно використовувати організаційно-економічні заходи розвитку галузі.

Одним із таких організаційних заходів є впровадження кластерної моделі розвитку, яка полягає у кооперації зусиль споріднених підприємств, фінансових, дослідницьких, навчальних, торгових структур та державних установ для спільного виробництва продукції, яка відповідає світовим стандартам [13, с. 39].

Для плодоовочевих консервних підприємств характерний високий рівень концентрації виробництва. Значна частка виробництва усіх основних видів плодоовочевої консервної продукції належить областям, які відносяться до Причорноморського соціально-економічного району - Одеській, Миколаївській та Херсонській. Саме у цих трьох областях зосереджено виробництво 22,95\% овочів, 9,05\% плодів та ягід, 44,6 \% соків фруктових та овочевих, 85,2 \% суміші соків фруктових та овочевих, 63,2 \% овочів консервованих натуральних за підсумками 2014 р. [14] (табл.2).

Таблиця 2

Розподіл виробництва плодоовочевої продукції між областями України*

\begin{tabular}{|l|c|c|c|c|c|}
\hline \multirow{2}{*}{ Області } & \multicolumn{5}{|c|}{ Частка області у загальному виробництві продукції } \\
\cline { 2 - 6 } & Овочі & $\begin{array}{c}\text { Плоди та } \\
\text { ягоди }\end{array}$ & $\begin{array}{c}\text { Соки фруктові } \\
\text { та овочеві, т }\end{array}$ & $\begin{array}{c}\text { Суміші соків } \\
\text { фруктових та } \\
\text { овочевих, т }\end{array}$ & $\begin{array}{c}\text { Овочі } \\
\text { консервовані } \\
\text { натуральні }\end{array}$ \\
\hline Вінницька & 4,74 & 12,11 & 12,80 & - & - \\
\hline Закарпатська & 3,08 & 6,65 & 0,78 & - & 1,33 \\
\hline Львівська & 4,98 & 4,95 & 9,70 & 62,18 & 27,47 \\
\hline Миколаївська & 5,10 & 1,60 & 24,17 & 22,06 & 9,70 \\
\hline Одеська & 4,54 & 3,70 & 20,02 & 0,93 & 26,08 \\
\hline Херсонська & 13,30 & 3,75 & 0,41 & - & 15,89 \\
\hline Черкаська & 3,69 & 1,90 & 0,07 & 85,18 & - \\
\hline Чернівецька & 2,41 & 1,8 & 1,96 & & 80,46 \\
\hline Разом & 41,86 & 36,47 & 69,90 & & - \\
\hline
\end{tabular}

*Розроблено автором на основі [14]

Провідні позиції за виробництвом плодів та ягід займає Вінницька область - для неї вирощування плодів та овочів є однією з галузей спеціалізації. При дефіциті переробних потужностей в регіоні, аграрні підприємства Вінниччини реалізують врожай на консервні заводи інших областей.

Загалом у межах України можливим є утворення кількох плодоовочевих кластерів. 
Одним із них може бути Причорноморський плодоовочевий кластер у межах Херсонської, Миколаївської, Одеської областей. Нами були визначені коефіцієнти локалізації виробництва плодоовочевої продукції для областей даного регіону, які показують відносну концентрацію виробництва плодоовочевої консервної продукції в перелічених областях (табл. 3).

Таблиця 3

Рівень локалізації виробництво плодоовочевої продукції*

\begin{tabular}{|r|c|c|c|c|}
\hline \multicolumn{1}{|c|}{ Показники } & \multicolumn{4}{|c|}{ Регіон } \\
\cline { 2 - 5 } & Разом & $\begin{array}{c}\text { Одеська } \\
\text { область }\end{array}$ & $\begin{array}{c}\text { Миколаївська } \\
\text { область }\end{array}$ & $\begin{array}{c}\text { Херсонська } \\
\text { область }\end{array}$ \\
\hline $\begin{array}{r}\text { Частка валового регіонального продукту у зага- } \\
\text { льному підсумку, \% }\end{array}$ & 8,1 & 4,6 & 2,1 & 1,4 \\
\hline Коефіцієнт локалізації виробництва & & & & \\
\hline Овочі & 2,83 & 0,99 & 2,43 & 9,50 \\
\hline Плоди та ягоди & 1,12 & 0,80 & 0,76 & 2,68 \\
\hline Соки фруктові та овочеві & 5,51 & 4,35 & 11,51 & 0,29 \\
\hline Суміші соків фруктових та овочевих & 10,52 & 4,80 & 29,61 & 0,67 \\
\hline Овочі консервовані натуральні & 7,81 & 2,11 & 13,08 & 18,63 \\
\hline
\end{tabular}

*Розроблено автором на основі [14]

Оскільки коефіцієнти локалізації для плодоовочевої консервної продукції перевищують одиницю, то можемо зробити висновок, що існують підстави для створення Причорноморського плодоовочевого кластеру в межах трьох південних областей України, що обумовлено історично, географічно та технологічно. У рамках окресленої території $є$ не лише необхідні сировинні ресурси та виробничі потужності 3 переробки плодів та овочів, а й профільні наукові установи, високий попит з боку населення, можливості експорту продукції до інших країн.

Позитивний вплив кластерної моделі розвитку на інвестиційний потенціал підприємств-учасників полягатиме у створенні механізму для реалізації наявних інвестиційних можливостей та появі принципово нових умов для розвитку. Збільшення потенціалу залучення інвестицій відбуватиметься через підвищення рівня інтегрованості підприємств, ріст продуктивності праці, більш повне використання виробничих потужностей. Потенціал відтворення інвестицій зростатиме внаслідок збільшення операційного левериджу (оптимізації структури витрат у рамках кластеру). Важливим фактором $є$ можливість акумулювання інвестиційних ресурсів для спільного впровадження інноваційних проектів аграрними та переробними підприємствами. Проблемним питанням формування плодоовочевого кластеру залишається узгодженість дій його учасників та ефективність механізмів управління продуктовою спеціалізацією в умовах обмеженості асортиментного ряду.

На основі виявлених вище закономірностей та окреслених практичних завдань доцільно запропонувати наступну схему організації і взаємодії учасників плодоовочевого кластеру (рис. 1).

На основі сучасного досвіду утворення кластерів у різних галузях економіки України та відповідну нормативну документацію, нами розроблено проект положення про Причорноморський плодоовочевий кластер. Визначено, що Причорноморський плодовочевий кластер - це група відокремлених юридичних осіб, які спеціалізуються на виробництві, зберігання, переробці та реалізації плодів та овочів, а також діяльність яких направлена на підвищення ефективності технологічних та організаційних процесів у даному регіоні.

Для забезпечення роботи кластеру доцільно сформувати Раду кластеру - дорадчий орган, який створюється 3 метою забезпечення ефективної діяльності Кластеру з урахуванням інтересів держави, регіону та учасників кластера. До його складу має входити по одному представнику від кожного учасника або групи учасників. Кожен учасник кластера має самостійно визначити основні завдання, які потрібні для його успішного розвитку, та сформувати їх у вигляді переліку задач, які стають базою для розробки Радою кластера конкретних заходів щодо вирішення цих завдань. Новими учасниками кластеру можуть бути суб'єкти, діяльність яких співпадає з напрямами роботи кластеру. У якості зобов'язань учасників кластеру визначено такі:

- додержувати положень установчих документів і виконувати рішення органів управління;

- сприяти кластеру у здійсненні ним своєї діяльності;

- нести інші обов'язки, якщо це передбачено діючим законодавством та установчими документами.

Запропоновано для прийняття рішень та реалізації положень цієї угоди створити наступні органи управління: загальні збори учасників; рада кластера; спільна робоча група.

Також передбачено створення посади координатора кластеру, який виконуватиме за дорученням ради кластеру представницькі та виконавчі функції без права втручатися у діяльність учасників кластера та представляти інтереси окремих учасників кластера.

Запропоноване положення може бути впроваджене у життя задля розвитку інвестиційного потенціалу плодоовочевих консервних підприємств. Ініціатором створення Причорноморського плодоовочевого кластеру можуть стати органи державної чи місцевої влади (обласні державні адміністрації), потужні переробні підприємства регіону або наукові організаціï. 


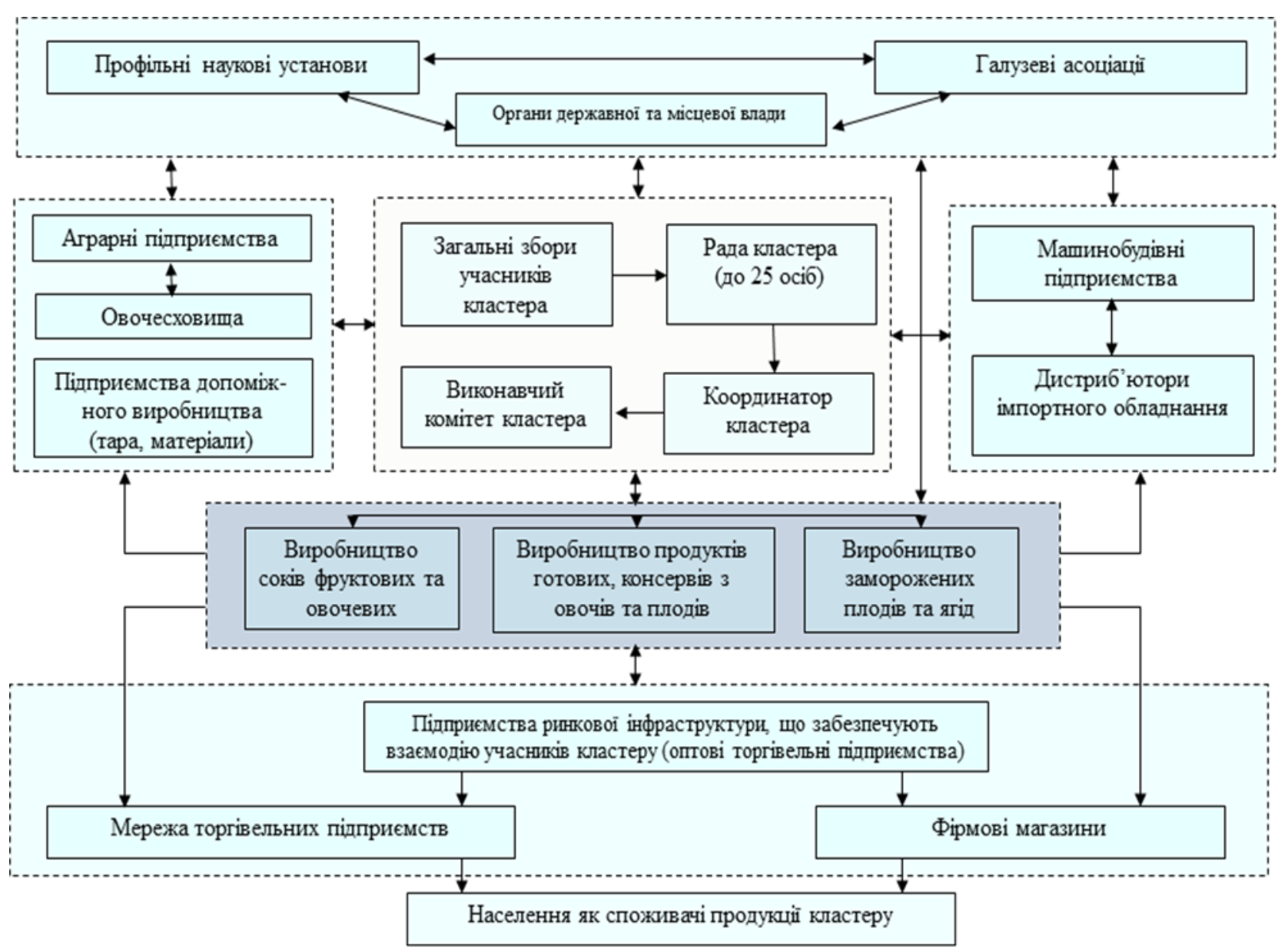

Рис. 1. Схема організації та взаємодії учасників плодоовочевого кластеру*

* Розроблено автором [15]

У разі впровадження запропонованої схеми організації та взаємодії учасників плодоовочевого кластеру відбудеться зростання часткових показників складових інвестиційного потенціалу (табл. 4).

Ефект від створення Причорноморського плодоовочевого кластера полягатиме в удосконаленні окремих складових інвестиційного потенціалу підприємств учасників кластеру. Відповідно відбудеться зростання комплексного показника рівня інвестиційного потенціалу підприємств.

Створення плодоовочевого кластеру спрямоване на вирішення ключових проблем галузі та дасть змогу створити принципово новий механізм реалізації та відтворення інвестиційного потенціалу плодоовочевих консервних підприємств.

Таблиця 4

Ефекти від впровадження організаційних заходів 3 підвищення інвестиційного потенціалу плодоовочевих консервних підприємств *

\begin{tabular}{|c|c|c|}
\hline $\begin{array}{c}\text { Складові } \\
\text { інвестиційного } \\
\text { потенціалу }\end{array}$ & Ефекти від впровадження організаційних заходів & $\begin{array}{l}\text { Прогноз зміни показників } \\
\text { інвестиційного потенціалу }\end{array}$ \\
\hline $\begin{array}{l}\text { Фінансова } \\
\text { складова }\end{array}$ & $\begin{array}{ll}- & \text { Оптимізація структури капіталу } \\
- & \text { Збільшення чистого оборотного капіталу } \\
- & \text { Залучення додаткових фінансових ресурсів } \\
- & \text { Зменшення дебіторської та кредиторської заборговано- } \\
\text { сті підприємств } & \end{array}$ & $\begin{array}{l}\text { - Оптимізація коефіцієнтів за- } \\
\text { гальної ліквідності, маневреності } \\
\text { власного капіталу та співвідно- } \\
\text { шення кредиторської й дебіторсь- } \\
\text { кої заборгованості }\end{array}$ \\
\hline $\begin{array}{c}\text { Виробничо- } \\
\text { комерційна } \\
\text { складова }\end{array}$ & 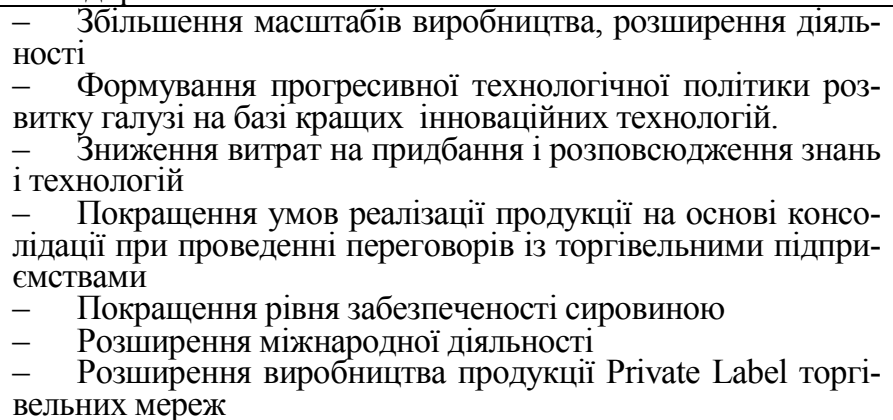 & $\begin{array}{l}\text { - } \text { Підвищення коефіцієнту ви- } \\
\text { користання виробничої потужнос- } \\
\text { ті } \\
- \text { Підвищення інтенсивності } \\
\text { оновлення основних засобів, фон- } \\
\text { довіддачі, зменшення коефіцієнту } \\
\text { зносу } \\
-\quad \text { Підвищення коефіцієнту обо- } \\
\text { ротності активів } \\
-\quad \text { Підвищення } \\
\text { продаж }\end{array}$ \\
\hline
\end{tabular}


Продовження таблиці 4

\begin{tabular}{|c|c|c|}
\hline $\begin{array}{l}\text { Ринкова } \\
\text { складова }\end{array}$ & $\begin{array}{l}\text { - Налагодження системи взаємодії між підприємствами } \\
\text { і запобігання виникненню корпоративних конфліктів між } \\
\text { учасниками кластеру }\end{array}$ & $\begin{array}{l}-\quad \text { Формування сприятливої кон- } \\
\text { куренції на ринку }\end{array}$ \\
\hline $\begin{array}{l}\text { Організаційна } \\
\text { складова }\end{array}$ & $\begin{array}{l}-\quad \text { Посилення вертикальної інтеграції підприємств у ра- } \\
\text { мках кластеру } \\
-\quad \text { Створення механізму співпраці з органами влади } \\
\end{array}$ & $\begin{array}{l}- \text { Приєднання консервних підп- } \\
\text { риємств до інтеграційних утворень }\end{array}$ \\
\hline $\begin{array}{l}\text { Кадрова } \\
\text { складова }\end{array}$ & 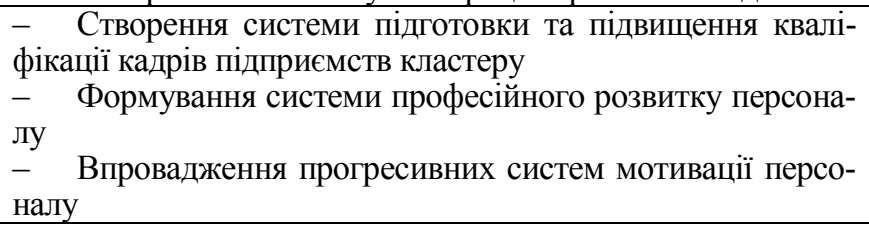 & $\begin{array}{l}- \text { Підвищення продуктивності } \\
\text { праці персоналу } \\
-\quad \text { Підвищення рівня умотивова- } \\
\text { ності персоналу } \\
-\quad \text { Інтенсифікація приросту ефек- } \\
\text { тивності трудового персоналу }\end{array}$ \\
\hline $\begin{array}{l}\text { Динамічна } \\
\text { складова }\end{array}$ & 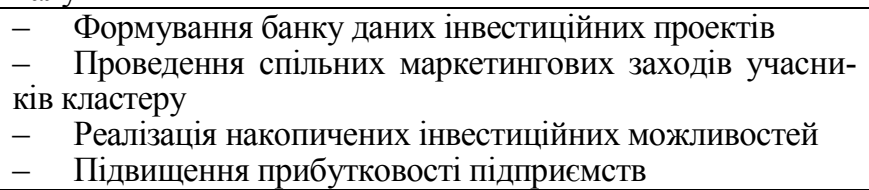 & $\begin{array}{l}-\quad \text { Збільшення частки ринку } \\
-\quad \text { Підвищення операційного леве- } \\
\text { риджу } \\
-\quad \text { Підвищення } \quad \text { рентабельності } \\
\text { активів }\end{array}$ \\
\hline
\end{tabular}

*Розроблено автором [15]

Висновки та перспективи подальших досліджень. Нами визначено та обгрунтовано ключовий організаційний напрям реалізації інвестиційного потенціалу плодоовочевих консервних підприємств, який полягає у впровадженні схеми організації та взаємодії учасників плодоовочевого кластеру на основі поєднання зусиль та економічних інтересів виробників плодів та ягід, переробних підприємств АПК, наукових установ та органів влади. Також визначено організаційні механізми створення Причорноморського плодоовочевого кластера, його мету, завдання, повноваження та обов'язки учасників і керівних органів. Перспективи подальших досліджень полягають у побудові математичної моделі для визначення можливого економічного ефекту від створення плодоовочевого кластера.

\section{Література}

1. Брижань I. А. Вплив кластерних об’єднань на розвиток підприємств і регіонів / І. А. Брижань, I. М. Савицька // Вісник Хмельницького національного університету. - 2011. - №2 . - С. 189-194.

2. Войнаренко М.П. Кластери в економіці: монографія / М.П. Войнаренко. - Хмельницький: ХНУ, ТОВ «Тріада-М», 2011. - 502 с.

3. Єпіфанова І.Ю. Кластерна модель як напрямок підвищення ефективності інвестиційної діяльності промислових підприємств/ І.Ю. Спіфанова // Вісник Хмельницького національного університету. Економічні науки. - 2009. - № 6. - Т.1. - С.24-27.

4. Іванов Ю.Б. Оцінка стійкості регіональних кластерних структур в аспекті їх ресурсного потенціалу / Ю.Б. Іванов, А.Д. Олійник // Вісник Національного університету Львівська політехніка. Проблеми економіки та управління. - 2009. - № 640. - С. 101-111.

5. ванченко Г. В. Розробка кластерної моделі розвитку регіону: методологічний підхід [Електронний ресурс] / Г. В. Іванченко // Ефективна економіка. - № $5 . \quad$ - $2013 . \quad$ - Режим доступу: http://www.economy.nayka.com.ua/?op=1\&z=2049.

6. Продіус І.П. Кластерна модель розвитку винної галузі [Електронний ресурс] / І.П. Продіус, О.Б. Бровкова, Т.І Адирова // Економіка: реалії часу. Науковий журнал. - 2012. - № 3-4 (4-5). - С. $218-222$.

7. Саблук П. Т. Кластеризація як механізм підвищення конкурентоспроможності та соціальної спрямованості аграрної економіки / П. Т. Саблук, М. Ф. Кропивко // Економіка АПК. - 2010. - № 1(183). - С. 3-12.

8. Porter M. E. Location, Competition, and Economic Development: Local Clusters in a Global Economy / M. E. Porter // Economic Development Quarterly. - 2000. - № 14. - C. 15-34.

9. Rosenfeld S. A. Bringing business clusters into the mainstream of economic development / S. A. Rosenfeld // European Planning Studies. - 1997. - № 5. - C. 3-23.

10. Waits M. J. The Added Value of the Industry Cluster Approach to Economic Analysis, Strategy Development, and Service Delivery / M. J. Waits // Economic Development Quarterly. - 2000. - № 14. - C. 35-50.

11. Asheim B. Clusters and Regional Development: Critical Reflections and Explorations / B. Asheim, P. Cooke, R. Martin // Growth and Change. - 2008. - № 39. - C. 372-375.

12. Статистичний щорічник України за 2014 рік / за ред. І. М. Жук. - К, 2014. - 586 с.

13. Вєтров О. Кластерна модель - ефективний інструмент економічного розвитку громади // Громадські ініціативи. - 2005. - № 1. - С. 39-42.

14. Статистичні дані щодо діяльності підприємств [Електронний ресурс] / Режим доступу: http://ukrstat.gov.ua/ 
15. Дідух С. М. Формування та оцінка інвестиційного потенціалу підприємств плодоовочевої консервної промисловості України. [Текст] : автореф. дис. .... канд. екон. наук : 08.00 .04 / С. М. Дідух. - Херсон: ХНТУ, 2013. - 20 c.

\author{
Дидух С.M. \\ кандидат экономических наук \\ кафедра экономики промышленности \\ Одесская национальная академия пищевых технологий \\ ул. Канатная, 112, г. Одесса, Украина, 65039 \\ E-mail: didukhsm@i.ua
}

\title{
ИСПОЛЬЗОВАНИЕ КЛАСТЕРНОЙ МОДЕЛИ ДЛЯ РЕАЛИЗАЦИИ ИНВЕСТИЦИОННОГО ПОТЕНЦИАЛА ПЛОДООВОЩНЫХ КОНСЕРВНЫХ ПРЕДПРИЯТИЙ
}

\begin{abstract}
Целью исследования является определение и обоснование организационного направления реализации инвестиционного потенциала плодоовощных консервных предприятий, который заключается во внедрении кластерной модели развития. В статье рассмотрены предпосылки использования кластерной модели развития для реализации инвестиционного потенциала плодоовощных консервных предприятий Украины. Рассчитан коэффициент локализации производства плодоовощных консервов в южных областях Украины. Его значения свидетельствуют о наличии условий для внедрения кластерной модели развития. Рассмотрены состояние и проблемы развития предприятий консервной отрасли: падение объемов производства происходит на фоне снижения потребления, уменьшения доходов населения, устаревшей материально-технической базы предприятий.

Определено и обосновано ключевое организационное направление реализации инвестиционного потенциала предприятий плодоовощной консервной промышленности - внедрение схемы организации и взаимодействия участников плодоовощного кластера на основе объединения усилий и экономических интересов производителей плодов и ягод, перерабатывающих предприятий АПК, научных учреждений и органов государственной и местной власти.

Предложена схема организации и взаимодействия участников плодоовощного кластера. Представлен организационный механизм создания Причерноморского плодоовощного кластера, его цели, задачи, полномочия и обязанности участников и руководящих органов. Представлены возможные эфффекты от внедрения организационных мероприятий по повышению инвестиционного потенциала плодоовощных консервных предприятий. Эфрфект от внедрения Причерноморского плодоовощного кластера будет заключаться в том числе в совершенствовании отдельных составляющих инвестиционного потенциала предприятий участников кластера и, соответственно, повышении экономической эфффективности данных предприятий.
\end{abstract}

Ключевые слова: кластерная модель развития, инвестиционный потенциал, плодоовощные консервные предприятия, плодоовощной кластер.

Didukh S.M.

Ph.D. in Economics

Department of Industrial Economics

Odessa National Academy of Food Technologies

Kanatna str., 112, Odessa, Ukraine, 65039

E-mail: didukhsm@i.ua

\section{USING THE CLUSTER MODEL FOR THE REALIZATION OF THE INVESTMENT POTENTIAL OF FRUIT AND VEGETABLE CANNING ENTERPRISES}

The main purpose of the article is to identify and study the organizational direction of the realization of the investment potential of fruit and vegetable canning enterprises, which is the implementation of the cluster development model. The article describes the prerequisites for using the cluster model of develop- 
ment for the realization of the investment potential of the fruit and vegetable canning enterprises in Ukraine. We calculated the coefficient of localization of production of canned fruits and vegetables in the southern regions of Ukraine. Its values indicate the presence of the conditions for the introduction of cluster model of development. The state and problems of the enterprises canning industry has been analyzed in the article. The fall in production occurs due to lower consumption, reducing incomes, outdated material and technical base of enterprises.

We have identified and substantiated the key organizational direction of the realization of the investment potential of the enterprises of fruit and vegetable canning industry - the introduction of the scheme of the organization and interaction of participants of fruit and vegetable cluster by combining the efforts and the economic interests of producers of fruits and berries, agricultural enterprises, academic institutions and state and local authorities. The scheme of the organization and interaction of participants of fruit and vegetable cluster has been proposed and substantiated.

We have presented an organizational mechanism of the creation of the Black Sea fruit and vegetable canning cluster, its goals, objectives, powers and obligations of the participants and decision makers. The possible effects of the introduction of organizational measures to improve the investment potential of the fruit and vegetable canning companies has been presented. The effect of introduction of the Black Sea fruit and vegetable cluster will be including in the improvement of the individual components of the investment potential of the enterprises cluster members and thus increase their economic efficiency.

Keywords: cluster development model, investment potential, fruit and vegetable canning industry enterprises, fruit and vegetable cluster.

\section{References}

1. Bryzhan, I., \& Savytska, I. (2011). Vplyv klasternykh ob'iednan na rozvytok pidpryiemstv i rehioniv. Visnyk Khmelnytskoho Natsionalnoho Universytetu, 2, 189-194.

2. Voinarenko, M. (2011). Klastery v ekonomitsi. Khmelnytskyi: KhNU, 502.

3. Iepifanova, I. (2009). Klasterna model yak napriamok pidvyshchennia efektyvnosti investytsiinoi diialnosti promyslovykh pidpryiemstv. Visnyk Khmelnytskoho Natsionalnoho Universytetu. Ekonomichni Nauky, 1(6), 24-27.

4. Ivanov, Y., \& Oliinyk, A. (2009). Otsinka stiikosti rehionalnykh klasternykh struktur v aspekti yikh resursnoho potentsialu. Visnyk Natsionalnoho Universytetu Lvivska Politekhnika. Problemy Ekonomiky Ta Upravlinnia, (640), 101-111.

5. Ivanchenko, H. (2013, October 25). Rozrobka klasternoi modeli rozvytku rehionu: Metodolohichnyi pidkhid. Retrieved August 17, 2015, from http://www.economy.nayka.com.ua/?op=1\&z=2049.

6. Prodius, I. (2012). Klasterna model rozvytku vynnoi haluzi. Ekonomika: Realii Chasu. Naukovyi Zhurnal, (3-4), 218-222.

7. Sabluk, P., \& Kropyvko, M. (2010). Klasteryzatsiia yak mekhanizm pidvyshchennia konkurentospromozhnosti ta sotsialnoi. Ekonomika APK., 1(183), 3-12.

8. Porter, M. (2000). Location, Competition, and Economic Development: Local Clusters in a Global Economy. Economic Development Quarterly, (14), 15-34.

9. Rosenfeld, S. (1997). Bringing business clusters into the mainstream of economic development. European Planning Studies, (5), 3-23.

10. Waits, M. (2000). The Added Value of the Industry Cluster Approach to Economic Analysis, Strategy Development, and Service Delivery. Economic Development Quarterly, (14), 35-50.

11. Asheim, B., Cooke, P., \& Martin, R. (2008). Clusters and Regional Development: Critical Reflections and Explorations. Growth and Change, (39), 372-375.

12. Zhuk, I. (2014). Statystychnyi Shchorichnyk Ukrainy Za 2014 Rik, 586-586.

13. Vietrov, O. (2005). Klasterna model - efektyvnyi instrument ekonomichnoho rozvytku hromady. Hromadski Initsiatyvy, (1), 39-42.

14. Statystychni dani shchodo diialnosti pidpryiemstv. (2013, September 6). Retrieved August 17, 2015, from http://ukrstat.gov.ua/

15. Didukh, S. (2013). Formation and evaluation of investment potential of enterprises canning Ukraine. Kherson.

Received 09 September 2015

Approved 23 September 2015

Available in Internet 26.12.2015 